\title{
MEDICAL STUDENTS' LEVELS OF EMPATHY AND STIGMA TOWARD THE MENTALLY ILL
}

\author{
Lidija Injac Stevović ${ }^{1,2}$, Tamara Radojičić ${ }^{2}$,Selman Repišti ${ }^{2}$ \\ ${ }^{1}$ Medical School of University of Montenegro \\ ${ }^{2}$ Psychiatric Clinic of Clinical Center of Montenegro, Podgorica
}

\begin{abstract}
The main aim of this paper was to investigate levels of empathy in medical students as well as their attitudes toward people with mental disorders. We recruited 144 students from the School of Medicine in Podgorica (Montenegro), out of which 37.7\% were males and $62.3 \%$ were females. The mean age of the sample was $21.85(S D=2.65)$. We designed Scale of attitudes toward mentally ill people (SAMIP), and principal component analysis revealed that this instrument could be divided into two subscales - Positive attitudes toward the mentally ill (PAMI, $\alpha=.903$ ) and Stigmatization of the mentally ill (SMI, $\alpha=.875$ ). These subscales had high levels of reliability (i.e. internal consistency). The second measure was Empathy Questionnaire which is a unidimensional tool with a very high level of internal consistency $(\alpha=.924)$. The results revealed a high positive correlation between empathy levels and positive attitudes towards people with mental illness, a low correlation of empathy with the year of study, a low negative correlation between stigmatizing the mentally ill and participants' age, as well as low positive correlations of proneness to stigma with students' GPA and expectations of their profession. Recommendations for further research in this field were listed as well.
\end{abstract}

Keywords: empathy, stigma, attitudes, mental disorders, medical students 


\section{Introduction}

Cultivating humanistic values and enhancing interpersonal skills is of fundamental importance for any human service venture. Communicating with patients is one of the essential activities of medical workers. Patient-physician communication has been shown to have a therapeutic effect in terms of supporting the healing process, as well as a positive effect on psychosocial outcomes such as quality of life, anxiety, depression, etc. [1]. Empathy appeared to be one of the most important elements of successful communication between physicians and patients. In addition to fostering relationship between patients and medical workers, higher levels of empathy relate to more precise diagnosis, increased patient engagement in taking care of their own health and better adherence to therapy [2].

Some authors define empathy as solely cognitive concept. According to them, empathy is a personal quality that represents the capacity of the physician to "stand in the patient's shoes" and to observe the world from the patients perspective [3]. This definition predominantly involves understanding another person's concerns. On the other hand, The Association of American Medical Colleges describes empathy as a concept that is composed of two components, both cognitive and affective. They define empathy as "considering oneself as opposite person and posits the development of empathy as important for improved patient-physician relationship" [2] This definition emphasizes the ability of physician to understand the patient's perspective and feelings, to communicate and check the accuracy of that understanding and to build relationship with patients based on this understanding.

Another important concept for building successful patient-physician relationship appeared to be stigma. It is one of the challenges that individuals who suffer from mental illness have to face on a daily basis. On one hand, they are concerned with symptoms and difficulties that stem from their conditions and on the other hand they are confronted with the stereotypes and prejudice that others have about mental disorders [4].

Stigma can lead to discrimination and is related to higher levels of feelings of helplessness of individuals with mental disorders. Furthermore, stigma is shown to have an influence on patients' interactions, social network and quality of life in general [5]. It interferes in all stages of diagnosis and treatment of all types of mental disorders. It can also affect the way people seek for help individually and have implications on the development of policy on a national level [6]. Harmful effects of stigma against mental illnesses can force people to avoid asking for help or to seek help in faith healers or religion. Corrigan and Watson make a distinction between public stigma and selfstigma [4]. According to them, both of these types of stigma include stereotype (negative beliefs about a particular group), prejudice (negative emotional reactions in line with these beliefs), and discrimination (avoiding this group of individuals). 
Public stigma refers to stigmatizing others whereas self-stigma encompasses negative beliefs and emotion toward oneself. Thus, stigmatizing not only have negative consequences on education, housing, and employment prospects of a specific group, but also on their feeling of helplessness [7].

Magalhães, Salgueira, Costa, and Costa carried out a study into determining the correlation between medical students' year of study and their levels of empathy [8]. This correlation was positive and statistically significant. A study conducted Duarte, Raposo, Rodrigues, and Branco yielded a similar (yet not statistically significant) trend in data [9].

As for stigma toward the mentally ill, Martinez, Vasquez, Nava, Smith, and Avilla discovered that grade point average (GPA) of students do not have impact on it [10]. These researchers concluded that psychologist express slightly less stigma toward this socially sensitive group than do non-psychologists.

The chief aim of the present study was the examination of the relationships among positive attitudes and stigmatization toward the mentally ill, empathy, expectations of medical profession, academic achievements (expressed as grade point average - GPA), and the following socio-demographic factors - age, year of study, and gender.

The following research questions emerged from the aim articulated above:

1. Are students' positive attitudes and stigmatization toward the mentally ill associated with empathy?

2. Are students' positive attitudes toward the mentally ill, their stigmatization, and empathy correlated with students' expectations of medical profession, their academic achievement, age, year of study, and gender?

3. Are their expectations of medical conditions associated with GPA and the aforementioned socio-demographic factors?

\section{Methods}

Participants

A total of 144 medical students from the School of Medicine in Podgorica (Montenegro) took part in this study. 138 students provided information on their gender and there were 52 males (37.7\% of them) and 86 females $(62.3 \%)$. As per participants' age, the youngest student was 18 while the oldest one was 35 years of age. Mean age was calculated as $M=21.85$, whereas $S D$ $=2.65$. Figure 1 displays number of participants in different years of study.

As shown below, most of our participants were in the first year of their study ( $\mathrm{n}=48$, i.e. $35.29 \%$ of those who provided this information) whereas there was only one student $(0.74 \%)$ who was in the sixth year of his/her study (Figure 1). 


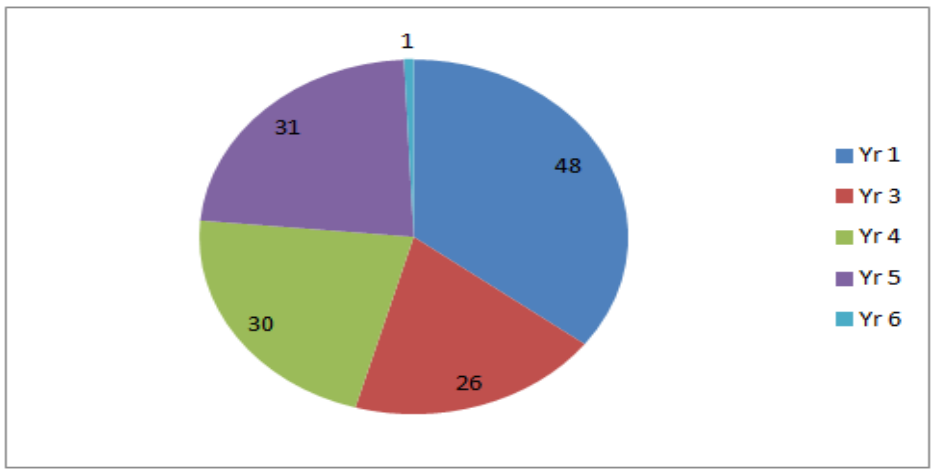

Figure 1. Sample structure by year of study

\section{Instruments}

The two main tools used in this study were as follows. The first one was Scale of attitudes toward mentally ill people (SAMIP), originally consisted of 24 items. It is given in the form of a 5-point Likert scale (ranging from 1 - "totally disagree" to 5 - "totally agree"). Principal component analysis (PCA) was conducted in order to investigate the latent structure of this instrument. Prerequisites for this kind of analysis had been met before it was applied $(\mathrm{KMO}=.836$, Bartlett's test of sphericity was statistically significant: $\chi^{2}=1883.783, d f=276, p<$ .001 , and sample size was more than five times greater compared to the number of items in this scale). PCA of this instrument yielded two latent dimensions, called Positive attitudes toward the mentally ill (PAMI) and Stigmatization of the mentally ill (SMI). One of the items of the PAMI dimension is „I believe mentally ill persons are violent" (reverse item), while example item of SMI dimension is „I consider mentally ill are stable only when they take regularly their medication". Together, they explained $48.79 \%$ of the variance in manifest variables (items). The eigenvalue of the first extracted component was $\lambda_{1}=6.360$ and this statistic for the second one was $\lambda_{2}=5.350$. These components explained $26.50 \%$ and $22.29 \%$ of the variance, respectively. Item analysis revealed that psychometric properties of the statement no. 13 were not acceptable (i.e. weak correlation with the total result on its subscale). Thus, this item was excluded from the subsequent analysis. Both PAMI and SMI had a high level of reliability, expressed as Cronbach's coefficient of internal consistency $(a=.903$ and $a$ $=.875$, respectively). After these analyses, we concluded that the first subscale should include 12 and the second one 11 items.

The second tool was Empathy Questionnaire [11] comprised of 15 items. Answers are provided on a 5-point Likert scale (which range is from 1 "totally disagree" to 5 - "totally agree"). Examples of items included in the questionnaire are the following: ,When I don't understand someone'e point of view, I ask questions to learn more.“, „I consider people's circumstances when I am talking to them.“ and „I try to imagine how I would feel in someone else's situation." PCA yielded one latent dimension which explained $47.51 \%$ of the 
items' variance (its eigenvalue was $\lambda=7.127$ ). Of course, the preconditions to applying PCA were fulfilled $\left(\mathrm{KMO}=.903 ; \chi^{2}=1081.722, d f=105, p<.001\right.$; and sample size was more than five times greater than the number of manifest variables/items). Two items (statements no. 3 and 11) of this questionnaire showed poor psychometric properties (i.e. their coefficients of item-total correlation were small) and further analysis was done without them. The internal consistency of Empathy Questionnaire was calculated as a $=.924(n=13)$ which indicated a very high level of its reliability.

Apart from these tools, we asked participants about their gender, age, grade point average (GPA), expectations of their profession ("On a scale from 1 to 5 , will your profession fulfill your expectations?", where 1 means "not at all" whereas 5 means "completely").

\section{Procedure}

The study was conducted during May, 2018. We used convenience sampling and we distributed the qustionnaires to the students in between their lectures at the School of Medicine in Podgorica. It took participants approximately 15 minutes to fill out the instruments. We complied with the rules of ethical conduct and treatment of participants in psychological research.

\section{Data Processing \& Analysis}

Data were analyzed with the help of SPSS 16.0 for Windows. First, participants' answers were coded and the database was created. We used parametric procedures within both descriptive and inferential statistics (Principal component analysis and Pearson's coefficient of correlation).

\section{Results}

First, we displayed main descriptive statistical values of the five key variables we were interested in (Table 1). Second, we we provided matrix of correlation coefficients, as indicators of relationships between the variables from Table 1 and some socio-demographics (Table 2).

Table 1. Descriptive statistical values of main variables

\begin{tabular}{lrrrrr}
\hline Variables & $\mathrm{N}$ & $\mathrm{Min}$ & $\mathrm{Max}$ & $\mathrm{M}$ & $\mathrm{SD}$ \\
\hline Positive attitudes toward the mentally ill & 137 & 1.00 & 4.75 & 3.51 & 0.87 \\
Stigmatization of the mentally ill & 139 & 1.00 & 4.91 & 2.72 & 0.77 \\
Empathy & 137 & 1.08 & 5.00 & 3.82 & 0.82 \\
Expectations of medical profession & 142 & 1.00 & 5.00 & 3.86 & 1.04 \\
GPA & 84 & 6.00 & 10.00 & 8.75 & 0.97 \\
\hline
\end{tabular}


As can be noticed in Table 1, participants expressed, on average, positive attitudes toward people with some mental illness $(M=3.51)$. Their mean estimate of the degree of stigmatization toward this socially sensitive group was slightly below the average $(M=2.72)$. Therefore, they moderately stigmatize mentally ill people. Next, medical students report relatively high levels of empathy $(M=3.82)$. In addition, their expectations regarding medical profession are above the average $(M=3.86)$. Finally, the mean value of their GPA was 8.75 , which indicated a high level of academic achievements.

\begin{tabular}{|c|c|c|c|c|c|c|c|c|}
\hline Variables & PAMI & SMI & EMP & EMPRO & GPA & YOS & A & G \\
\hline $\begin{array}{l}\text { Positive attitudes } \\
\text { toward } \\
\text { the mentally ill } \\
\text { (PAMI) }\end{array}$ & 1 & -.012 & $.668^{* * *}$ & .104 & .070 & .168 & -.009 & .075 \\
\hline $\begin{array}{l}\text { Stigmatization of } \\
\text { the } \\
\text { mentally ill (SMI) }\end{array}$ & & 1 & .025 & $.189^{*}$ & $.244^{*}$ & -.151 & $-.174 *$ & .114 \\
\hline Empathy (EMP) & & & 1 & .144 & .070 & $.268 * *$ & .100 & .137 \\
\hline $\begin{array}{l}\text { Expectations of } \\
\text { medical } \\
\text { profession } \\
\text { (EMPRO) }\end{array}$ & & & & 1 & $\begin{array}{l}.403 * * \\
*\end{array}$ & $-.369 * * *$ & $-.322 * * *$ & .100 \\
\hline $\begin{array}{l}\text { Grade point aver- } \\
\text { age } \\
\text { (GPA) }\end{array}$ & & & & & 1 & $-.460 * * *$ & $-.508 * * *$ & -.126 \\
\hline $\begin{array}{l}\text { Year of study } \\
\text { (YOS) }\end{array}$ & & & & & & 1 & $.756 * * *$ & -.087 \\
\hline Age (A) & & & & & & & 1 & -.050 \\
\hline Gender (G) & & & & & & & & 1 \\
\hline
\end{tabular}

As displayed in Table 2, students' positive attitudes toward people with some mental disorder were in a high, positive, and statistically significant correlation with their level of empathy $(r=.668, p<.001)$. On the other hand, students' tendencies to stigmatize this population were not in a statistically significant relationship with their levels of empathy.

When we analyzed the correlates of positive attitudes toward the mentally ill, their stigmatization, and empathy of medical students, we determined that stigmatizing this population was in a weak, positive, and statistically significant correlation with students' expectations of medical profession $(r=.189, p<.05)$ and their GPA $(r=.244, p<.05)$. In addition, stigmatization tendencies were in a small, negative, and statistically significant correlation with students' age. Empathy was in a small, positive, and statistically significant correlation with year of study $(r=.268, p<.01)$. In contrast, none of the three mentioned variables did not correlate significantly with participants' gender. 
Lastly, students' expectations of medical profession were in a moderate, positive, and statistically significant correlation with their GPA $(r=.403$, $p<.001)$, and in low, negative, and statistically significant correlations with their year of study $(r=-.369, p<.001)$ and age $(r=-.322, p<.001)$. Additionally, these type of expectations showed statistically insignificant relationship with students' gender.

\section{Discussion}

Taking into account the results obtained in this study, it is obvious that none of the research questions yielded completely positive answers. In other words, some of the relationships between the analyzed variables were statistically significant whereas others were not.

Generally speaking, medical students from Montenegro reported positive attitudes toward people with mental illness. They also reported high levels of empathy; however, their proneness to the stigmatization of this socially sensitive group was slightly below the average level of the scale used to measure it. In addition, positive attitudes toward the mentally ill are followed by higher levels of empathy.

Interestingly, medical students with higher GPA tended to stigmatize the mentally ill more, compared to those who had lower academic achievements. The proneness to stigmatization decreases as participants become older. Furthermore, their level of empathy increases as their year of study increases. This finding was in accordance with that obtained in a study conducted by Magalhães et al. (2011) [8]. These authors reported higher levels of empathy in medical students in senior year, compared to a group of freshmen. Besides, Duarte and this colleagues (2016) noticed the increase in empathy scores over the study/course; however, the differences were not statistically significant [9].

Medical students' tendency to stigmatize the mentally ill was related to their levels of expectation with regard to medical profession. To put it in other words, we obtained unexpected results that show that those who had high levels of expectations of medical profession were more prone to stigmatization. Majority of those with high expectations of medical profession have also high GPA, which can indicate their ambitiousness and dedication toward their personal professional development. It might be anticipated that majority of medical students are interested in patients with somatic diseases. In addition to this, School of Medicine in Podgorica has only one course within its syllabus that deals with psychiatric disorders. This can be a possible explanation of lower sensitivity of medical students toward vulnerable groups of people, such as mentally ill persons.

Our results showed no gender influences on participants' attitudes toward the mentally ill, stigmatization of the same population, their levels of empathy, and their expectations of medical profession. In contrast, statistically significant gender differences in medical students' levels of empathy were 
found in two other studies and their authors reported higher levels of empathy in favor of female medical students $[12,13]$.

The main shortcoming of this study was socially desirable responding which is very common in social sciences and humanities. The second disadvantage of the present study was that lots of participants from our sample did not provide their GPA. Hence, the correlation coefficients were calculated with data obtained on a smaller sample in this case. The third one encompassed the scale used for measuring attitudes and stigmatization regarding the mentally ill. This scale does not make a distinction between various types (categories) of mental illness Namely, attitudes and levels of stigma could differ depending on which mental disorder (schizophrenia, bipolar disorder, alcoholism) they refer to.

Some practical implications of the obtained results can be summarized as follows:

1. psychologists (or other mental health professionals) should work with medical students in order to help them decrease their tendencies to stigmatize the mentally ill;

2. empathy levels in medical students should be reinforced immediately in the first year of their study (e.g. their teachers and teaching assistants could serve them as role models and promote the atmosphere of which empathy is one of the crucial elements);

3. when fostering empathy, attitudes toward the mentally ill are becoming more positive.

Future studies could investigate the relationships between personality traits of medical doctors and their levels of empathy. Researchers in this field could also examine the effect of interaction between gender and year of study on attitudes toward the mentally ill and the stigmatization of this population. Moreover, further studies could shed light on the association between social/emotional intelligence level of medical students and their perception of people with mental disorders.

\section{Conclusion}

This study shed light on one of the topics extremely relevant in the context of educating medical professionals as well as similar professionals (including, for instance, psychologists, social workers, etc.).

Positive attitudes toward mentally ill seemed to be closely linked to levels of empathy. However, stigmatization and empathy were not in a significant relationship with each other. The relationship between participants' proneness to stigmatization and their age was negative indicating decrease in levels of stigmatization as medical students got older.

Regarding other variables, expectations of medical profession proved to be more positive if somebody has higher GPA and if $s /$ he is in a lower year of study. Next, levels of empathy and stigmatization was were not influenced by students' gender. Lastly, positive attitudes toward the mentally ill and empathy for them were not influenced by participants' age. 


\title{
NIVO EMPATIJE I STIGMATIZACIJE PREMA OSOBAMA SA MENTALNIM POREMEĆAJIMA OD STRANE STUDENATA MEDICINSKOG FAKULTETA
}

\author{
Lidija Injac Stevović ${ }^{1,2}$, Tamara Radojičić ${ }^{2}$, Selman Repišti ${ }^{2}$ \\ ${ }^{1}$ Medicinski fakultet Univerziteta Crne Gore \\ ${ }^{2}$ Psihijatrijska klinika Kliničkog centra Crne Gore, Podgorica
}

\begin{abstract}
Apstrakt: Glavni cilj ovog rada bio je istražiti nivo empatije kod studenata medicine kao i njihove stavove prema osobama sa mentalnim poremećajem. Ispitali smo 144 studenta Medicinskog fakulteta u Podgorici (Crna Gora), od čega su $37.7 \%$ bili muškarci, a $62.3 \%$ žene. Prosjek dob ispitanika bila je $21.85(\mathrm{SD}=2.65)$. Dizajnirali smo Skalu stavova prema osobama sa mentaslnim poremećajima (SAMIP), a analizom glavnih komponenti otkriveno je da se ovaj instrument može podijeliti u dvije podskale - Pozitivan odnos prema osobama sa mentalnim poremećajima (PAMI, $\alpha=.903$ ) i Stigmatizacija osoba sa mentalnim poremećaima (SMI, $\alpha=.875$ ). Ove podkategorije imale su veoma dobru pouzdanost (tj. unutrašnju konzistentnost). Druga mjera bio je Upitnik za empatiju koji je jednodimenzionalni instrument $s$ vrlo visokim nivoom unutarnje konzistentnosti $(\alpha=.924)$. Rezultati su otkrili visoku pozitivnu povezanost između nivoa empatije i pozitivnog stava prema osobama s mentalnim bolestima, nisku povezanost empatije s godinom studija, nisku negativnu povezanost između stigmatizacije mentalno obolelih i dobi učesnika, kao i nisku pozitivnu korelaciju sklonosti ka stigmatiziranju sa prosjekom ocjena i očekivanjima od njihove profesije. Navedene su i preporuke za dalja istraživanja u ovoj oblasti.
\end{abstract}

Ključne riječi: empatija, stigma, stavovi, mentalni poremećaji, studenti medicine 


\section{References}

1. Neumann M, Edelhauser F, Tauschel D, Fisher M, Wirtz M, Woopen C, Haramati A, Scheffer C. Empathy decline and its reasons: a systematic review of studies with medical students and residents. Acad. Med. 1999;86:996-1009.

2. Nunes P, Williams S, Sa B, Stevenson K. A study of empathy decline in students from five health disciplines during their first year of training. IJME 2011;2:12-7.

3. Hojat M, Gonnella JS, Nasca TJ, Mangione S, Vergare M, Magee M. Physician empathy: definition, components, measurement, and relationship to gender and specialty. Am J Psychiatry 2002;159:1563-9.

4. Corrigan PW, Watson AC. Understanding the impact of stigma on people with mental illness. World Psychiatry 2002;1:16-20.

5. Mas A, Hatim A. Stigma in mental illness: attitudes of medical students towards mental illness. Med J Malaysia 2002;57:433-44.

6. Naeem F, Ayub M, Javed Z, Irfan M, Haral F, Kingdon D. Stigma and psychiatric illness. A survey of attitude of medical students and doctors in Lahore, Pakistan. J Ayub Med Coll Abbottabad 2006;18:46-9.

7. Imran N, Haider II. The stigmatization of psychiatric illness: What attitudes do medical students and family physicians hold towards people with mental illness? Pak J Med Sci 2007;23:318-22.

8. Magalhães E, Salgueira AP, Costa P, Costa MJ. Empathy in senior year and first year medical students: a cross-sectional study. BMC Medical Education 2011;11:52-8.

9. Duarte ML, Raposo ML, Rodrigues PJ, Branco MC. Measuring empathy in medical students, gender differences and level of medical education: An identification of a taxonomy of students. Inv Ed Med. 2016;5:253-60.

10. Martinez V, Vasquez C, Nava E, Smith K, Avilla R. Factors affecting stigma toward people with schizophrenia and video-based interventions for stigma reduction. UC Merced Undergraduate Research Journal 2017;10:1-9.

11. Gaumer Erickson AS, Soukup JH, Noonan PM, McGurn L. Empathy questionnaire. Lawrence, KS: University of Kansas, Center for Research on Learning; 2016.

12. Duarte MI, Branco MC, Raposo ML, Rodrigues PJ. Empathy in medical students as related to gender, year of medical school and specialty interest. South East Asian Journal of Medical Education 2015;9:50-3.

13. Bratek A, Bulska W, Bonk M, Seweryn M, Krysta K. Empathy among physicians, medical students, and candidates. Psychiatria Danubina 2015;27:48-52.

Prof. dr Lidija INJAC STEVOVIĆ, Psihijatrijska klinika Klinčki centar Crne Gore, Podgorica, Crna Gora

Professor Lidija INJAC STEVOVIĆ, MD, PhD, Clinic for Psychiatry, Clinical Center of Montenegro, Podgorica, Montenegro

E-mail: injac119@gmail.com 